\title{
CARACTERIZAÇÃO DOS DEPÓSITOS SEDIMENTARES DE CÁSSIA E SUA RELAÇÃO COM A ZONA DE FALHA DE CÁSSIA, SUDOESTE DE MINAS GERAIS
}

\author{
CHARACTERIZATION OF THE SEDIMENTARY DEPOSITS OF CÁSSIA AND ITS \\ RELATIONSHIP WITH THE CÁSSIA FAULT ZONE, SOUTHWEST OF MINAS GERAIS
}

\section{José Eduardo SARTORI ${ }^{1}$, Mitsuru ARAI², Norberto MORALES ${ }^{3}$, Letícia Severina de QUADROS $^{4}$}

${ }^{1}$ Programa de Pós-graduação em Geociências e Meio Ambiente. Instituto de Geociências e Ciências Exatas - UNESP. Rio Claro. E-mail: sartori.j3@gmail.com

${ }^{2}$ UNESPetro - Instituto de Geociências e Ciências Exatas - UNESP. E-mail: mitsuru.arai@ gmail.com ${ }^{3}$ Departamento de Petrologia e Metalogenia - Instituto de Geociências e Ciências Exatas - UNESP. E-mail: n.morales@unesp.br ${ }^{4}$ Programa de Pós-graduação em Geografia. Instituto de Geociências e Ciências Exatas - UNESP.

E-mail: leticia_unesp@yahoo.com.br

\author{
Introdução \\ Contexto Geológico-Geomorfológico Regional \\ Materiais e Métodos \\ Palinologia \\ Caracterização Sedimentar Dos Depósitos \\ Análise Palinológica \\ Indícios de Deformação \\ Gênese e Evolução dos Depósitos Sedimentares \\ Evidências de Reativação da Zona de Falha de Cássia \\ Considerações Finais \\ Agradecimentos \\ Referências
}

\begin{abstract}
RESUMO - Os depósitos sedimentares jovens da região de Cássia, no sudoeste de Minas Gerais, são conhecidos e intensamente explotados como matéria-prima para cerâmica vermelha desde a década de 1930. Entretanto, tais materiais geológicos foram pouco estudados, geralmente de maneira sucinta em trabalhos ainda inéditos. Além disso, a cobertura sedimentar se mostra fortemente controlada pelos traços da Zona de Falha de Cássia, uma importante estrutura pré-cambriana que corta e deforma o embasamento cristalino da região. Neste contexto, o presente trabalho tem por objetivo descrever e mapear os depósitos sedimentares, investigando a relação deles com a referida zona de falha. Assim, foi caracterizado um pacote sedimentar de composição predominantemente pelítica, referente ao registro de um paleolago, com a entrada episódica e localizada de leques aluviais, associados com a movimentação/reativação tectônica dos traços da Zona de Falha de Cássia durante o Quaternário.

Palavras-chave: Reativação de Falha, Palinologia, Quaternário, Neotectônica.
\end{abstract}

\begin{abstract}
The sedimentary deposits of the Cássia region in southwestern Minas Gerais are known and intensely exploited as raw material for red ceramics since the 1930s. However, such geological materials have been poorly studied, generally succinctly in works still unpublished. In addition, the sedimentary cover is strongly controlled by the traces of the Cássia Fault Zone, an important preCambrian structure that cuts and deforms the crystalline basement of the region. In this context, the present work has the objective of describing and mapping the sedimentary deposits, investigating their relation with the fault zone. It was characterized a sedimentary package of predominantly pelitic composition, related to the registration of a paleolake with the episodic and localized entry of alluvial fans associated with the tectonic movement/reactivation of the traces of the Cássia Fault Zone during the Quaternary.

Keywords: Fault Reactivation, Palinology, Quaternary, Neotectonics.
\end{abstract}

\section{INTRODUÇÃO}

Os depósitos sedimentares argilosos de Cássia, no sudoeste de Minas Gerais (Figura 1), são conhecidos e explotados desde a década de 1930, segundo relatos dos oleiros mais antigos da região, mas as descrições geológicas pioneiras relativas a esses sedimentos surgiram somente após meio século (Oliveira et al., 1984). Posteriormente, eles foram estudados sucintamente em alguns trabalhos de formatura (Azzi, 2009; Sartori, 2009; Farias et al. 2012), e em mapeamento geológico em escala 1:100.000
(Morales et al., 2008), fruto da parceria entre a UNESP e a CPRM, todos inéditos.

Vários trabalhos (e.g., Santos, 1999; Neves et al., 2003; Gontijo-Pascutti et al., 2009) reconhecem na região Sudeste do Brasil a ocorrência de depósitos cenozoicos, cuja gênese e evolução estão intimamente associadas a antigas descontinuidades do embasamento cristalino. A reativação tectônica de antigas estruturas é a hipótese mais utilizada para explicar tais feições. Para consolidar a hipótese, 
é necessário realizar estudos cuidadosos e sistemáticos, com a adoção de critérios robustos que confirmem a reativação. Entretanto, são raros os trabalhos que tratam adequadamente esse tema. Holdsworth et al. (1997) fizeram uma revisão geral sobre reativação tectônica de estruturas e listaram cinco conjuntos de critérios:

- Critérios geométricos - estão fundamentados na similaridade de orientação ou paralelismo de feições geológicas e estruturas mais novas com outras mais antigas ou profundas;

- Critérios estratigráficos - envolvem repetições, modificações e deformações no pacote sedimentar, bem como evidências estratigráficas indiretas;

- Critérios estruturais - superposição de indicadores cinemáticos e modificações dos produtos de deformação dentro de falhas e zonas de cisalhamento;
- Critérios geocronológicos - datação direta de produtos de deformação e evidências indiretas de relação de corte de litotipos de idade conhecida/estimada;

- Critérios neotectônicos - registro sísmico moderno e histórico de falhas, e deslocamento de feições geomorfológicas e antropogênicas ao longo dos traços de falha.

No contexto dos critérios de reativação tectônica propostos por Holdsworth et al. (1997), a ocorrência de depósitos sedimentares quaternários na região de Cássia (MG) permitiu a investigação a respeito de reativações ao longo dos traços da Zona de Falha de Cássia, motivando a realização deste trabalho que objetiva, além do estudo e mapeamento dos referidos depósitos sedimentares, o reconhecimento de sua relação com a zona de falha e posterior deformação.

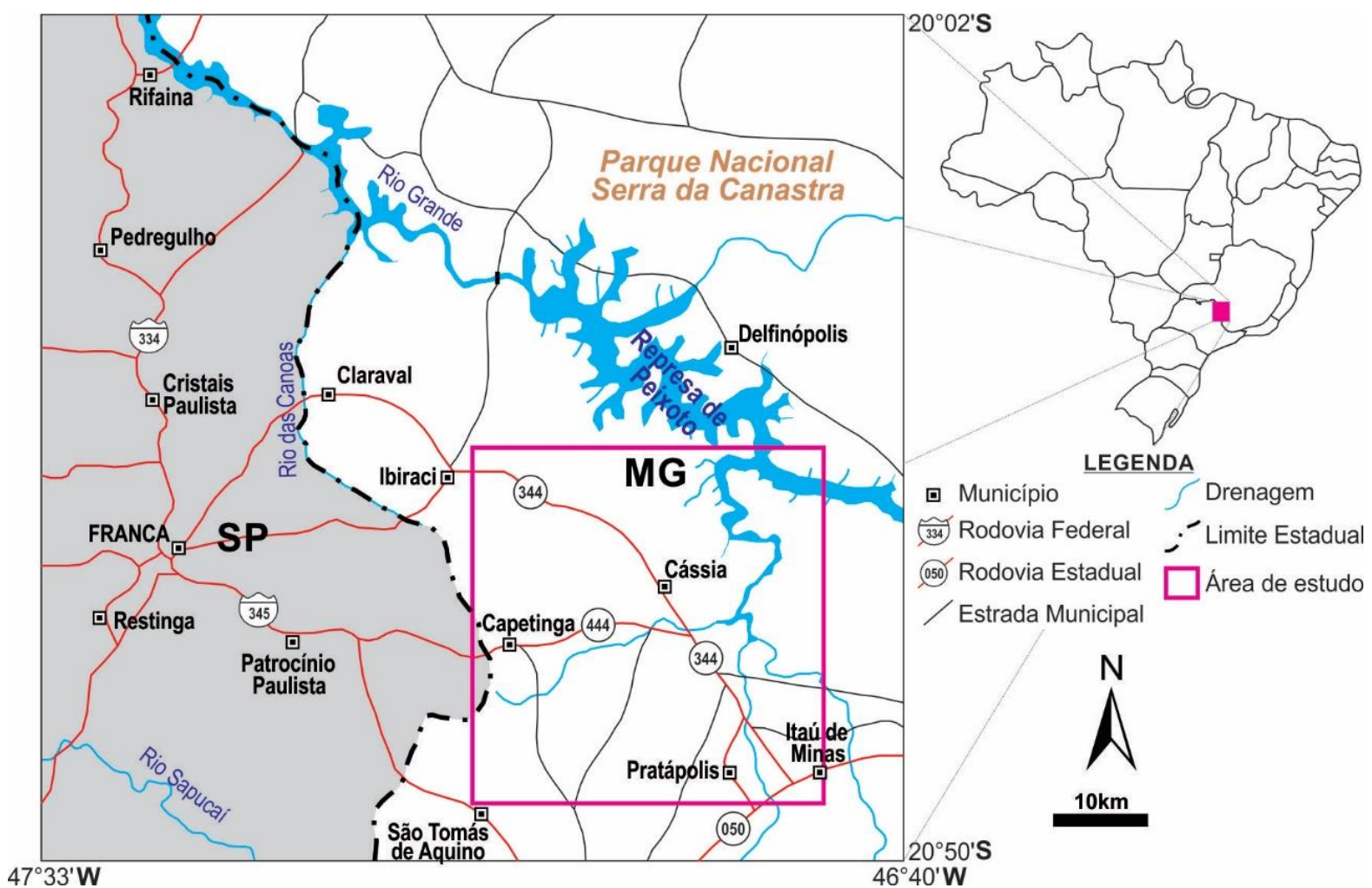

Figura 1 - Mapa de localização da área de estudos, destacando os municípios, limites estaduais, bem como as principais drenagens e rodovias da região.

\section{CONTEXTO GEOLÓGICO-GEOMORFOLÓGICO REGIONAL}

A região de Cássia apresenta características geomorfológicas particulares, estando posicionada na transição entre duas importantes regiões geomorfológicas (Figura 2) de relevo contrastante: os Planaltos da Bacia do Paraná e os Planaltos da Canastra. A primeira entidade geomorfológica é marcada por relevo monoclinal, caracterizado por topos aplainados com suave caimento topográfico e estrutural para o interior da bacia, a oeste. As frentes escarpadas voltadas para leste completam o conjunto, configurando típico relevo cuestiforme (Gatto et al., 1983). Tais feições podem atingir cotas superiores a $1.100 \mathrm{~m}$ de altitude na região.

O quadro geológico é apresentado na figura 3. O registro mais antigo da Bacia do Paraná na região é dado por lamito, arenito arcoseano, arenito conglomerático, diamictito e conglo- 
merado avermelhados do Grupo Itararé. O pacote sedimentar está assentado diretamente sobre o embasamento cristalino em discordância erosiva, perfazendo espessura máxima local estimada em $60 \mathrm{~m}$ (Oliveira et al., 1984). Tratam-se de rochas sedimentares depositadas em ambiente glacial proximal (Milani et al., 2007), de idade stephaniana (Neocarbonífero), baseada em palinomorfos (Daemon \& Quadros, 1970).

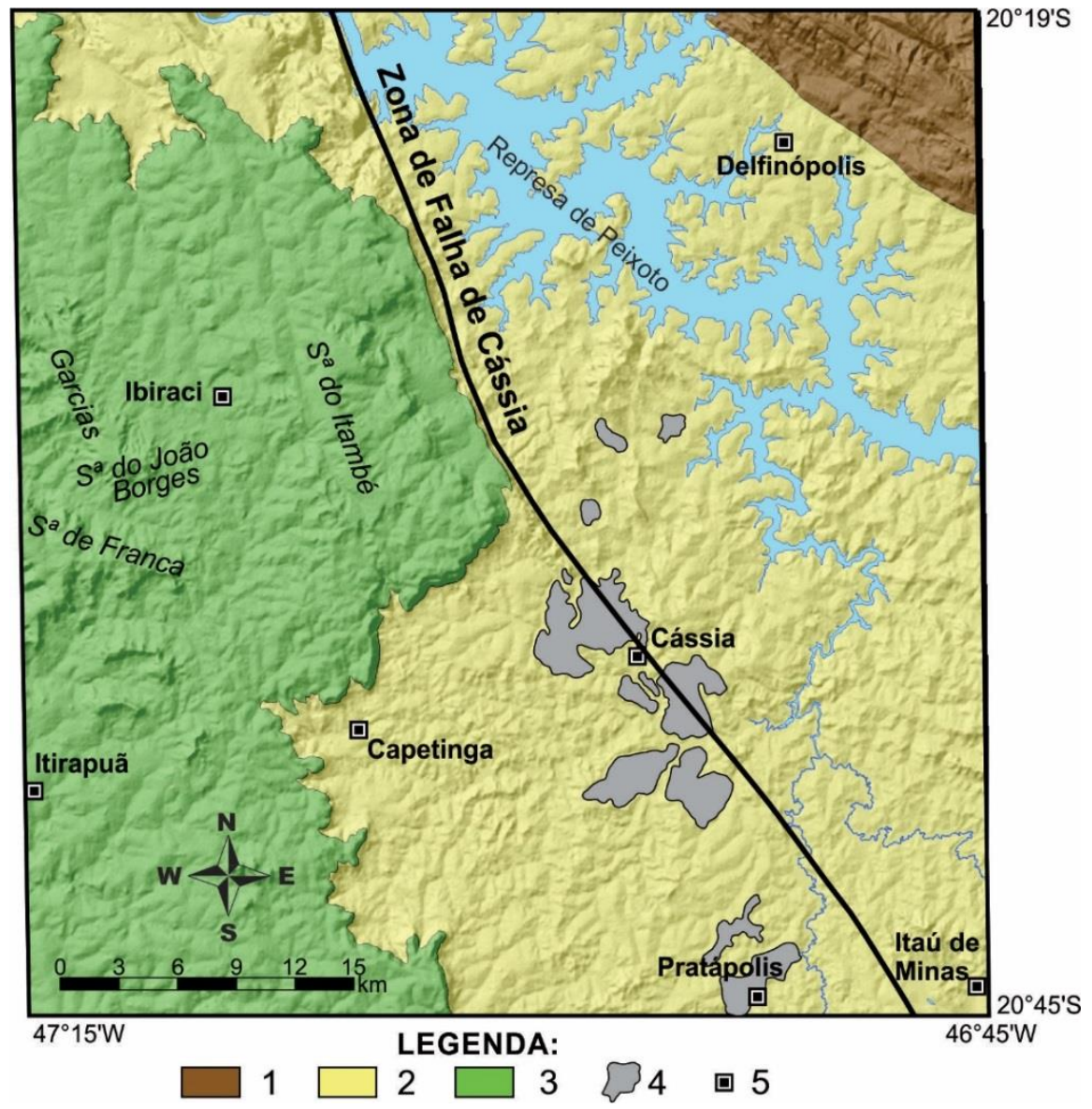

Figura 2 - Mapa de relevo sombreado da área de estudos, com indicação das regiões geomorfológicas envolvidas.

Legenda: (1) Serra da Canastra; (2) Patamares da Canastra; (3) Planaltos da Bacia do Paraná. (4) Bacias sedimentares jovens, (5) Sede de município. Fonte: Elaborado pelo primeiro autor com base em dados SRTM, observações de campo no trabalho de Gatto et al. (1983).

Coluna estratigráfica apresentada, ocorre o arenito quartzoso, de granulação fina a média, bem selecionado, com grãos foscos e bem arredondados, com coloração creme a rosa, da Formação Botucatu, que exibe estratificação cruzada de grande porte, de origem eólica em ambiente desértico.

Subordinadamente, ocorrem lamitos, siltitos e arenitos lamíticos interpretados como fácies lacustres (Soares \& Landim, 1973). Sua espessura máxima é estimada em $50 \mathrm{~m}$ (Morales et al., 2008) a $60 \mathrm{~m}$ (Perdoncini, 2003) na região estudada. Milani et al. (2007) posicionaram esta unidade estratigráfica no Cretáceo Inferior.

As dunas arenosas do paleodeserto Botucatu foram cobertas por uma série de derrames de lavas basálticas e intrudidas por diabásios da Formação Serra Geral. Trata-se de basalto de coloração verde a cinza-escuro, granulação muito fina a fina, afanítica e estrutura maciça. Segundo IPT (1981), a mineralogia principal é dada por plagioclásio cálcico (andesina e labradorita) e clinopiroxênio (augita e pigeonita), tendo olivina, titanita e apatita como minerais acessórios mais comuns.

O pacote constituído pela intercalação dos arenitos eólicos da Formação Botucatu com os basaltos/diabásios da Formação Serra Geral, com leve mergulho para o oeste possibilitou o desenvolvimento das cuestas, marcantes nos planaltos da Bacia do Paraná.

Os basaltos da Formação Serra Geral exibem espessura média em torno de $25 \mathrm{~m}$, espessandose para o interior da bacia (Perdoncini, 2003). Segundo Turner et al. (1994), datações Ar/Ar indicam que o evento Serra Geral teria ocorrido entre 126,8 $\pm 2,0$ e 137,8 \pm 0,7 Ma (Eocretáceo). 


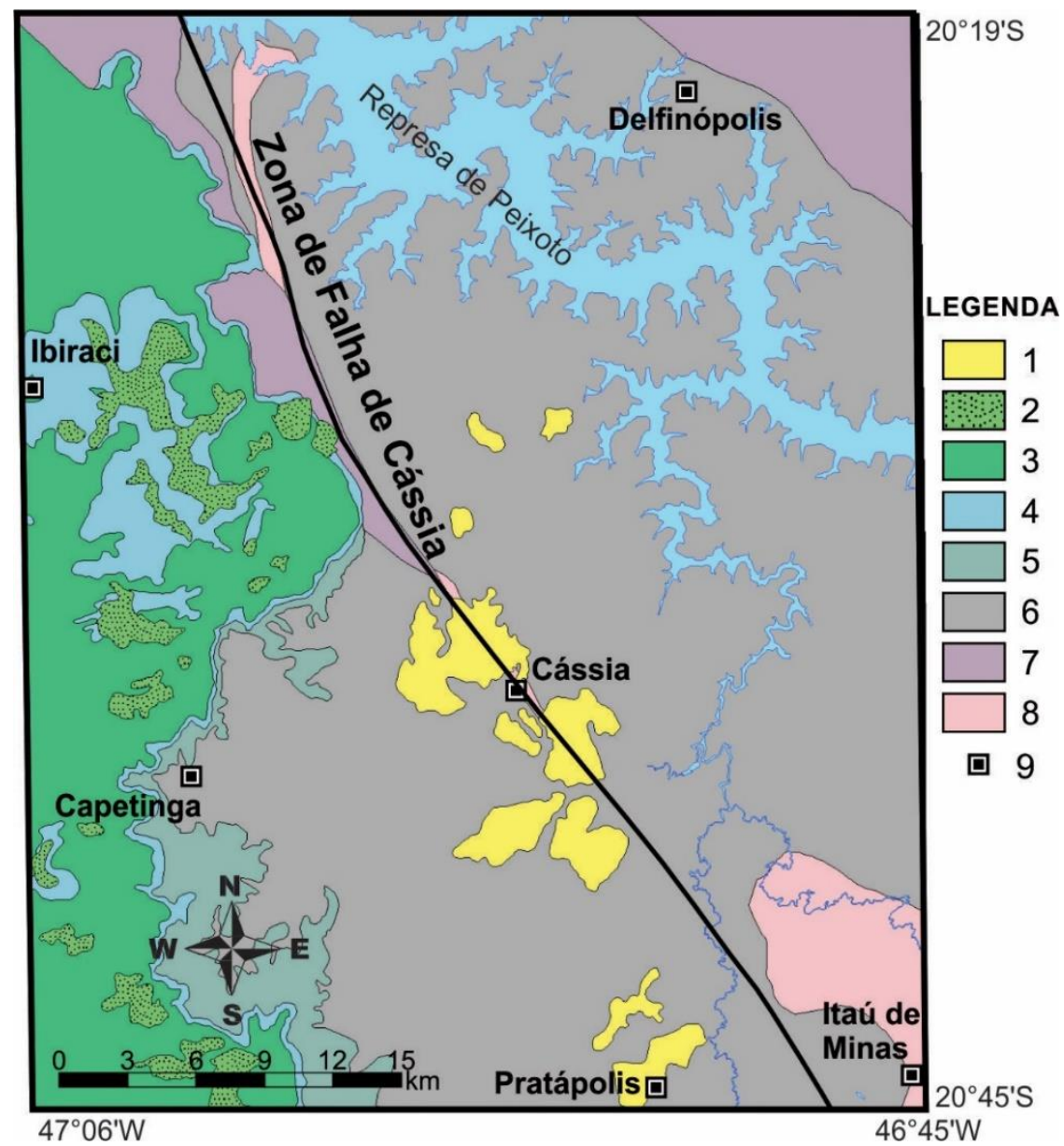

Figura 3 - Mapa geológico da área de estudos. Legenda: 1- Depósitos sedimentares quaternários; Bacia do Paraná: 2- Grupo Bauru, 3- Formação Serra Geral, 4- Formação Botucatu, 5- Grupo Itararé; Embasamento cristalino: 6- Grupo Araxá (predomínio de xistos), 7- Grupo Araxá (intercalações de xistos e quartzitos), 8- Complexo Campos Gerais; 9- Sede de município. Fonte: Elaborado pelo autor com base nos trabalhos de campo e dados compilados de Oliveira et al. (1984), Brasil (2003) e Perdoncini (2003).

A sedimentação pós-basáltica da região está registrada por arenito, arenito conglomerático, conglomerado e lamito, que ocorrem distribuídos pelas principais elevações da área (serras de Franca, dos Agudos, dos Garcias, e do João Borges). Segundo Perdoncini (2003), os arenitos são imaturos textural e mineralogicamente (ricos em feldspato) e maciços, portando eventualmente estratificações cruzadas. O lamito, por sua vez, apresenta coloração vermelha amarelada a acastanhada e aspecto mosqueado. Estes tipos de rocha são atribuídos ao Grupo Bauru.

O Grupo Bauru foi depositado em ambiente continental sob condições semiáridas a desérticas (Milani et al., 2007). Segundo Fernandes (1998), a sedimentação se deu através de um sistema de leques aluviais retrabalhados por sistema fluvial entrelaçado, e lençóis de areia nas partes distais. Também podem ocorrer intercalações subordinadas de rochas vulcânicas alcalinas, os analcimitos Taiúva (Fernandes \& Coimbra, 2000).

A origem da sedimentação do Grupo Bauru está diretamente relacionada ao desenvolvimento do

Soerguimento do Alto Paranaíba (Hasui \& Haralyi, 1991; Batezelli \& Ladeira, 2016) e do magmatismo alcalino neocretáceo gerador da província ígnea homônima. Gravina et al. (2002) apontaram presença expressiva de fragmentos de perovskita $\mathrm{e}$ apatita, minerais típicos e relativamente abundantes em rochas alcalinas, na composição mineral da Formação Uberaba (Grupo Bauru), o que evidencia que o Soerguimento do Alto Paranaíba atuou como área-fonte do Grupo Bauru (Hasui \& Haralyi, 1991).

Segundo Perdoncini (2003), o contato entre o Grupo Bauru e os basaltos da Formação Serra Geral é erosivo, e sua espessura varia de 3 a $10 \mathrm{~m}$, respectivamente a leste e a oeste da região de Franca.

Ultrapassando os limites da Bacia do Paraná para leste, adentra-se na unidade geomorfológica Patamares da Canastra, subdivisão dos Planaltos da Canastra. Trata-se de uma região topograficamente deprimida, posicionada em altitudes entre 600 e $800 \mathrm{~m}$, cujo relevo é caracterizado por colinas amplas com topos planos e vertentes 
convexas (Gatto et al., 1983). Esta unidade está assentada sobre as rochas metamórficas do Grupo Araxá e, subordinadamente, do Complexo Campos Gerais, no contexto geotectônico da Faixa Brasília Meridional.

O Grupo Araxá corresponde a uma sequência essencialmente metassedimentar de composição original psamo-pelítica, depositada em um contexto de margem continental passiva (Simões, 1995), com pequena contribuição de rochas metabásicas toleíticas, cuja geoquímica indica como protólitos basaltos continentais e do tipo EMORB (Correia \& Girardi, 1989; Valeriano \& Simões, 1997). Deste modo, a referida unidade estratigráfica é composta por micaxisto, quartzito, gnaisse, filito e anfibolito subordinado. A idade da sedimentação foi estimada em $0,9 \mathrm{Ga}$ (idades $\mathrm{U}-\mathrm{Pb}$ em rutilo de anfibolito) por Valeriano et al. (2004). Associações minerais presentes nos metassedimentos indicam condições de metamorfismo variando entre fáceis xisto verde zona da biotita nas proximidades do contato com o embasamento, evoluindo até o fácies anfibolito superior, atingindo condições de anatexia no topo do pacote (Zanardo, 1992; Simões, 1995).

As rochas do Grupo Araxá são cortadas e intensamente deformadas pela Zona de Falha de Cássia. Esta estrutura é descrita por Sartori (2018) como uma zona de falha oblíqua com movimentação principal transcorrente sinistral, com extensão total de aproximadamente $95 \mathrm{~km}$, segundo a direção geral NNW-SSE. A deformação é de caráter dúctil-rúptil, e está registrada pela formação de típicos milonitos de baixo grau (sensu Trouw et al., 2010), com associações minerais indicativas de metamorfismo em fácies xisto verde, zona da clorita. Além disso, duas lentes delgadas compostas por gnaisses e migmatitos fortemente milonitizados, atribuídos ao Complexo Campos Gerais, são interpretadas como lascas do embasamento embutidas tectonicamente no Grupo Araxá em decorrência da movimentação da Zona de Falha de Cássia.

Segundo Sartori (2018), a Zona de Falha de Cássia foi reativada no Neocretáceo como uma falha normal com bloco baixo a sudoeste. Tal evento tectônico está registrado através de falhas discretas e rochas de falha eminente-mente rúpteis, como brechas tectônicas, cataclasitos e até pseudotaquilito superpostos à antiga trama milonítica.

Os depósitos sedimentares estudados estão assentados diretamente sobre as rochas do embasamento cristalino, na região limitada, de modo geral, entre os traços da Zona de Falha de Cássia (a leste) e as escarpas erosivas da Bacia do Paraná (a oeste), como mostram os mapas das figuras 2 e 3 .

\section{MATERIAIS E MÉTODOS}

\section{Palinologia}

A palinologia corresponde ao estudo dos palinomorfos, ou seja, todos os organismos encontrados no resíduo insolúvel aos ácidos inorgânicos, provenientes do tratamento de rochas sedimentares de diferentes idades. Deste modo, são englobados pólens, esporos, dinoflagelados, quitinozoários, fungos, protistas e outros restos orgânicos (Uesugui, 1979).

Neste contexto, o processo de amostragem e tratamento das amostras são cruciais para obter o sucesso na recuperação dos palinomorfos e, consequentemente, na análise palinológica. Assim, procedeu-se a coleta de pelitos preferencialmente de coloração cinza escuro a preto, denotando riqueza em matéria orgânica preservada. A amostragem se deu em cavas para extração de argila utilizada por cerâmicas e olarias, popularmente conhecidas como "barreiros". Nos afloramentos contendo espessas camadas deste material, procedeu-se a coleta de material em diferentes níveis, buscando verificar possíveis variações no registro palinológico.

Todos os procedimentos foram realizados no Laboratório de Palinologia do UNESPetro/Rio Claro. O tratamento das amostras seguiu o método proposto por Uesugui (1979), com as modificações introduzidas por Arai (2017). Assim, foram utilizadas cerca de $50 \mathrm{~g}$ de cada amostra. $\mathrm{O}$ material foi colocado em um béquer de vidro de $1.000 \mathrm{ml}$, onde se adicionou $500 \mathrm{ml}$ de água destilada. Procedeu-se a agitação deste até a obtenção de uma solução homogênea. $\mathrm{O}$ béquer foi colocado em agitador magnético e, assim que formou redemoinho, adicionou-se hexametafosfato de sódio em pó em volume igual ao da amostra. A solução foi mantida no agitador magnético durante 8 horas para completa dissolução/desagregação do material. Em seguida, a solução foi deixada em repouso por 12 horas para decantar, após o qual a fase líquida sobrenadante foi descartada. Adicionou-se água até completar novamente $1.000 \mathrm{ml}$, repetindo-se o procedimento de agitação manual, decantação 
e descarte do material sobrenadante.

A partir da segunda lavagem, o tempo de descarte pós-decantação pode ser reduzido sucessivamente (e.g., 6, 3, 2 e 1 hora). A etapa de lavagem foi encerrada quando o líquido sobrenadante ficou limpo após o repouso de uma hora.

O resíduo decantado foi submetido ao peneiramento em malha de $10 \mu \mathrm{m}$ de abertura sob água corrente. $\mathrm{O}$ peneiramento prosseguiu até que não houvesse mais material em suspensão passante pela peneira. $O$ material retido na peneira seguiu para separação por líquido pesado. Para tanto, foi utilizada uma solução de cloreto de zinco $\left(\mathrm{ZnCl}_{2}\right)$ com densidade de 2,0 para a retirada dos componentes inorgânicos (quartzo, silte e outros minerais). $\mathrm{O}$ resíduo e a solução de $\mathrm{ZnCl}_{2}$ foram colocados em tubo de ensaio de $50 \mathrm{ml}$ que foi submetido à centrifugação a $4.000 \mathrm{rpm}$ por 30 minutos. O componente inorgânico foi para o fundo do tubo, e o resíduo orgânico, flutuante na solução, foi transferido para outro tubo de ensaio para ser lavado três vezes com água destilada. O resíduo orgânico final foi seco a temperatura ambiente e montado em lâmina de vidro para análise ao microscópio óptico convencional. Opcionalmente, o resíduo seco pode ser montado em stub para ser analisado ao microscópio eletrônico de varredura.

\section{CARACTERIZAÇÃO SEDIMENTAR DOS DEPÓSITOS}

Os depósitos sedimentares em foco estão distribuídos predominantemente entre os municípios de Cássia e Pratápolis, e também mais ao norte do primeiro, na localidade de
Lajeado, como mostra o mapa da figura 4. As principais ocorrências sedimentares se referem a cavas de argila ativas e inativas, olarias artesanais e abandonadas, bem como cerâmicas.

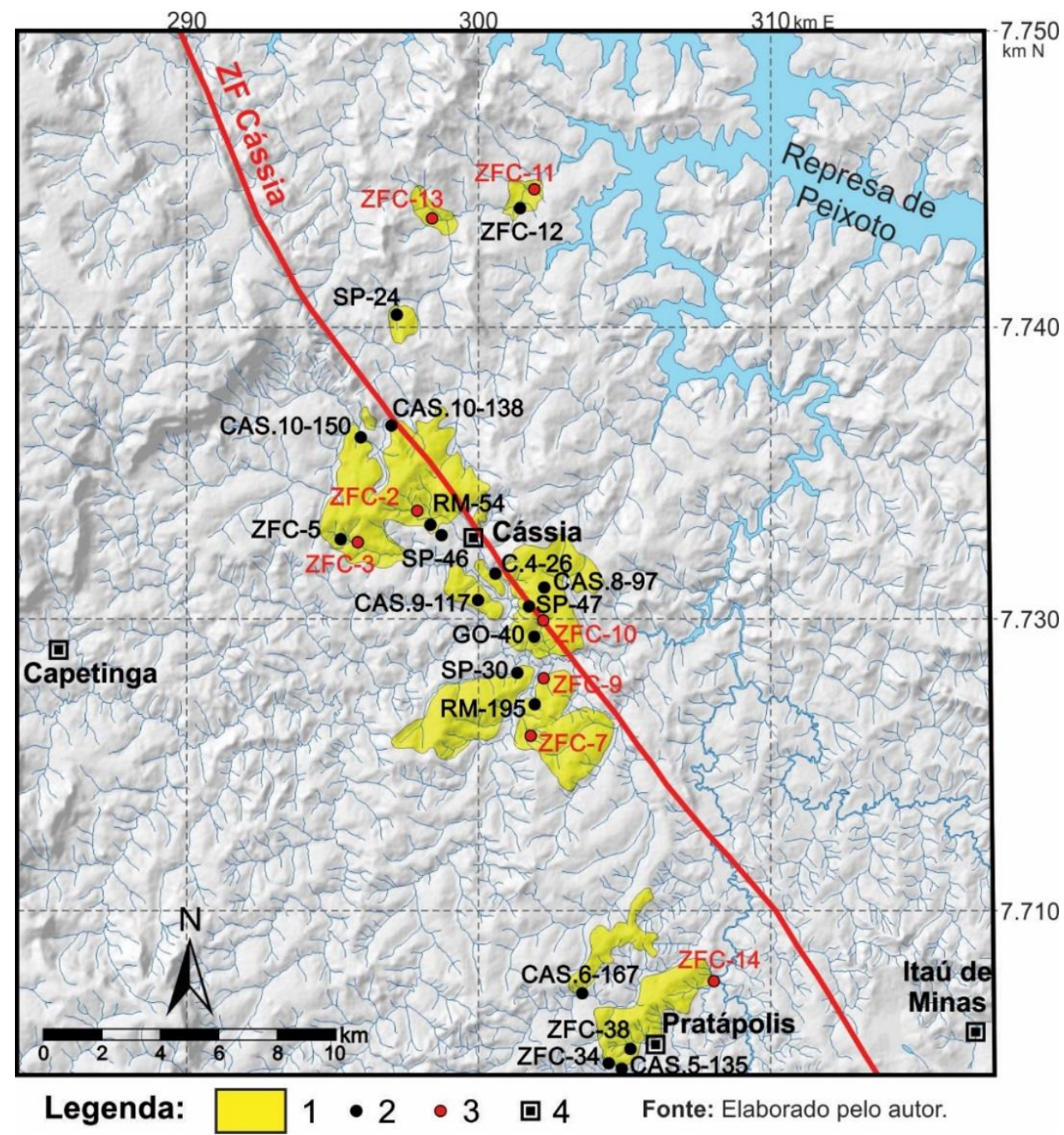

Figura 4 - Mapa de distribuição geográfica dos depósitos sedimentares da região de Cássia-Pratápolis. Ao fundo relevo sombreado (iluminação segundo o azimute N45) obtido a partir de dados de interferometria de radar/SRTM. Legenda: 1 Depósitos sedimentares quaternários; 2 - Afloramento estudado; 3 - Afloramento amostrado para palinologia; 4 - Sede de município. 
Os afloramentos descritos e mapeados estão posicionados ao longo de interflúvios situados até $140 \mathrm{~m}$ acima do nível atual das drenagens locais, sendo erodidos por estas últimas. Os depósitos sedimentares ocupam parte das bacias hidrográficas de algumas das principais drenagens da região, representadas pelos córregos da Água Limpa, da Antinha e Lajeado, Ribeirão São Pedro e o Rio Santana. Além disso, há um grande número de outras ocor-rências de sedimentos quaternários associados à planície aluvionar atual das drenagens locais.

De modo geral, a cobertura sedimentar estudada apresenta espessuras variando entre 0,5 a 9,0 m. Este último valor foi obtido a partir do perfil de uma sondagem rotativa realizada na cava de argila de uma cerâmica nas proximidades de Pratápolis (ponto ZFC-14) até atingir o embasamento cristalino. Tais observações associadas ao posicionamento topográfico das ocorrências sedimentares sugerem que os depósitos sedimentares em apreço apresentem espessuras expressivas, da ordem de algumas dezenas de metros. Neste sentido, Oliveira et al. (1984) e Zanardo et al. (2008) estimaram espessuras entre 40 e $50 \mathrm{~m}$ para os sedimentos.

A ocorrência de espessa camada de solo, que podem atingir espessuras locais de até $5,0 \mathrm{~m}$, recobrindo o pacote sedimentar dificultam o trabalho de mapeamento deste último. Trata-se de uma cobertura pedogenética composta por material areno-argiloso de coloração castanhoavermelhada a mosqueada. Nas proximidades das feições mais elevadas do relevo, ocorre material similar ao descrito anteriormente, portanto linha contínua e irregular de seixos (stone lines) na base, configurando material oriundo de rampa de colúvio.

O pacote sedimentar mapeado é caracterizado pela ocorrência extensiva e marcante de argilito preto, rico em matéria orgânica e altamente plástico (Figura 5A), que se torna rígido após dessecação. Tal material é intensamente explotado como matéria-prima para cerâmica vermelha, pelo uso intensivo de retroescavadeiras, mascarando as estruturas sedimentares. Apesar disso, ainda é possível reconhecer localmente laminação horizontal entre níveis mais argilosos ou com minerais mais claros, indicando sedimentação em ambiente lacustre.

$\mathrm{O}$ argilito apresenta porções ou transições arenosas, o que lhe confere aspecto grumoso, sendo denominado informalmente pelos oleiros de "argila borra de café". Além disso, o pelito pode ainda exibir concentrações locais de muscovita em forma de bolsões irregulares. Mais raramente, foi observada a ocorrência de grânulos e seixos elípticos de até $10 \mathrm{~cm}$ de comprimento compostos por quartzo e quartzito disseminados pela rocha (Figura 5B). Este litotipo forma camadas com espessura variando entre $30 \mathrm{~cm}$ a 3,0 $\mathrm{m}$ (Figura 6).

Outro pelito de ocorrência extensiva é o siltito, que transiciona lateralmente para termos mais argilosos e/ou arenosos, prevalecendo estes últimos. O litotipo apresenta coloração cinza clara (Figura 5C), transicionando lateralmente para termos avermelhados e amarelados ou manchados. Há ainda uma variedade do siltito argiloso de coloração cinza azulada com manchas castanhas popularmente chamada de "argila carijó" muito apreciada pelos oleiros e ceramistas.

O siltito pode conter, localmente, grânulos e seixos angulosos de quartzo (Figura $5 \mathrm{C}$ ), alguns cobertos por uma fina película de óxido de ferro, bem como agregados de muscovita dispersos pela rocha. Esta litologia se apresenta na forma de camadas de $40 \mathrm{~cm}$ a 3,0 $\mathrm{m}$ de espessura. As maiores espessuras registradas dos pelitos correspondem aos depósitos situados nos arredores do município de Cássia.

Além dos sedimentos finos observou-se importante contribuição de termos mais grossos no registro sedimentar dos perfis levantados, como psamitos e psefitos (Figura 6). O arenito é quartzoso, friável, granulação fina a média ou média a muito grossa, mal selecionado, coloração amarela, cinza a branco. O psamito geralmente é maciço, podendo exibir localmente estratificação cruzada, indicando a participação de correntes no processo de sedimentação.

$\mathrm{O}$ arenito ocorre formando delgadas lentes ou camadas entre 15 e $70 \mathrm{~cm}$ de espessura intercaladas aos siltitos e argilitos (Figura 5D). Também foram observados arenitos conglomeráticos, coloração castanho-amarelado, portando seixos angulosos de quartzito e muscovita xisto, constituindo camadas de 30 a $60 \mathrm{~cm}$ de espessura. Entretanto, nas proximidades de Pratápolis (ponto ZFC-14) uma sondagem rotativa interceptou uma camada de arenito de 4,5 $\mathrm{m}$ de espessura assentada diretamente sobre o embasamento cristalino. O litotipo é portador de fragmentos de troncos, caules e raízes parcialmente 
carbonificados (Figura 5E). Este material é extraído por dragagem, seco ao sol e peneirado/classificado para ser vendido como material de construção civil na região.

Oliveira et al. (1984) descreveram o arenito como arcoseano, inconsistente, coloração ver- melho-rosada, granulação fina a média, subanguloso. $\mathrm{O}$ psamito apresenta estratificação cruzada tangencial de médio porte na base, perfazendo um pacote arenoso com 20 a $25 \mathrm{~m}$ de espessura, muito mais expressivo que o observado neste trabalho.

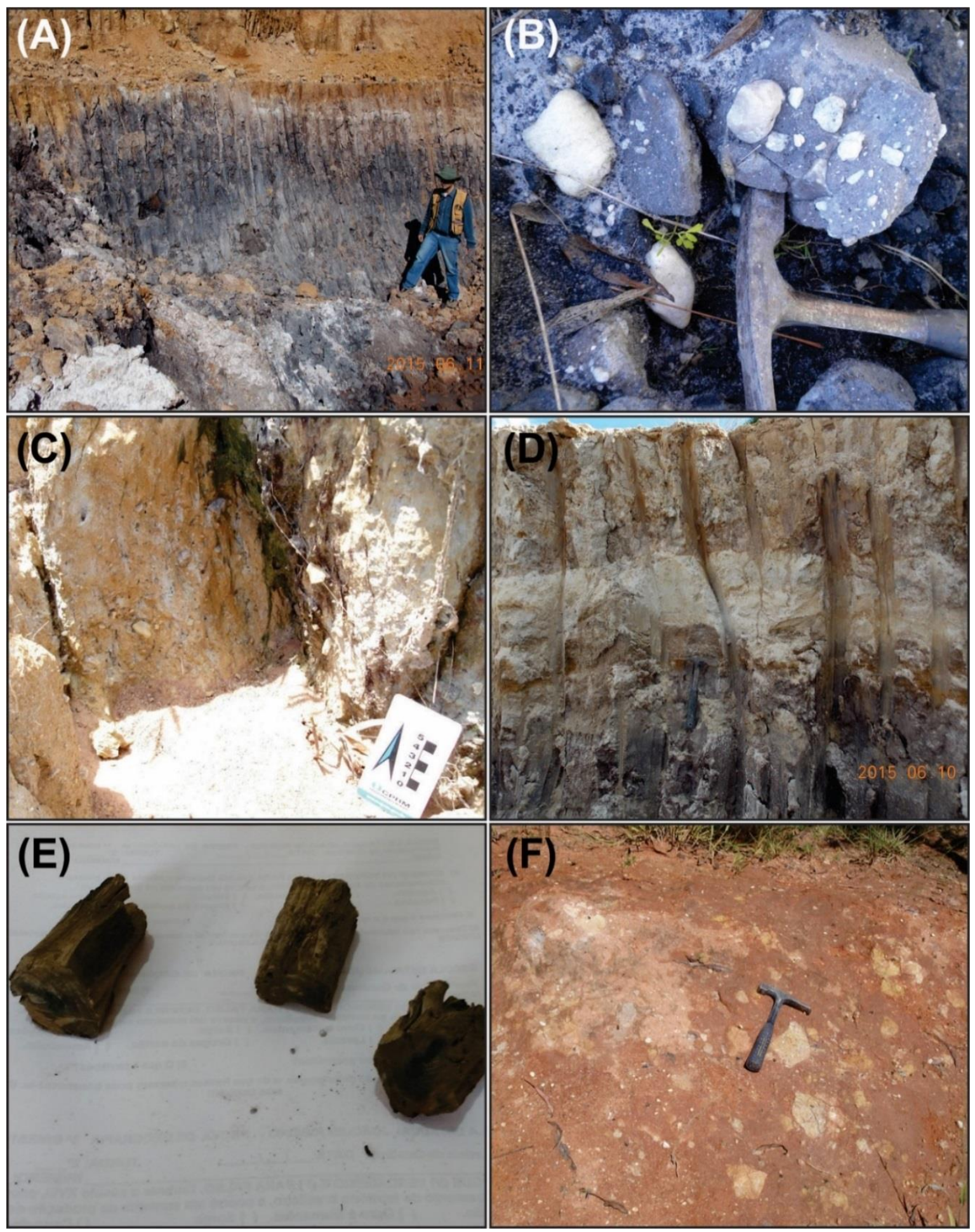

Figura 5 - A) Frente de lavra de barreiro exibindo argilito preto, rico em matéria orgânica, plástico, localmente com contribuição arenosa (ZFC-7). B) Argilito preto contendo grânulos e seixos de até $10 \mathrm{~cm}$ de comprimento compostos por quartzo e quartzito disseminados pela rocha (ZFC-12). C) Afloramento de siltito arenoso, cinza claro, contendo grânulos e seixos de quartzo (SP-46). (D) Camada de arenito quartzoso cinza claro em meio ao siltito arenoso no topo e o argilito preto na base (ZFC-2). E) Pequenos caules parcialmente carbonificados presentes em arenito (ZFC-14). F) Aspecto geral da brecha sedimentar, exibindo fragmentos angulosos de até $20 \mathrm{~cm}$ de quartzo, quartzito, mica xisto e arenito (SP-46). 


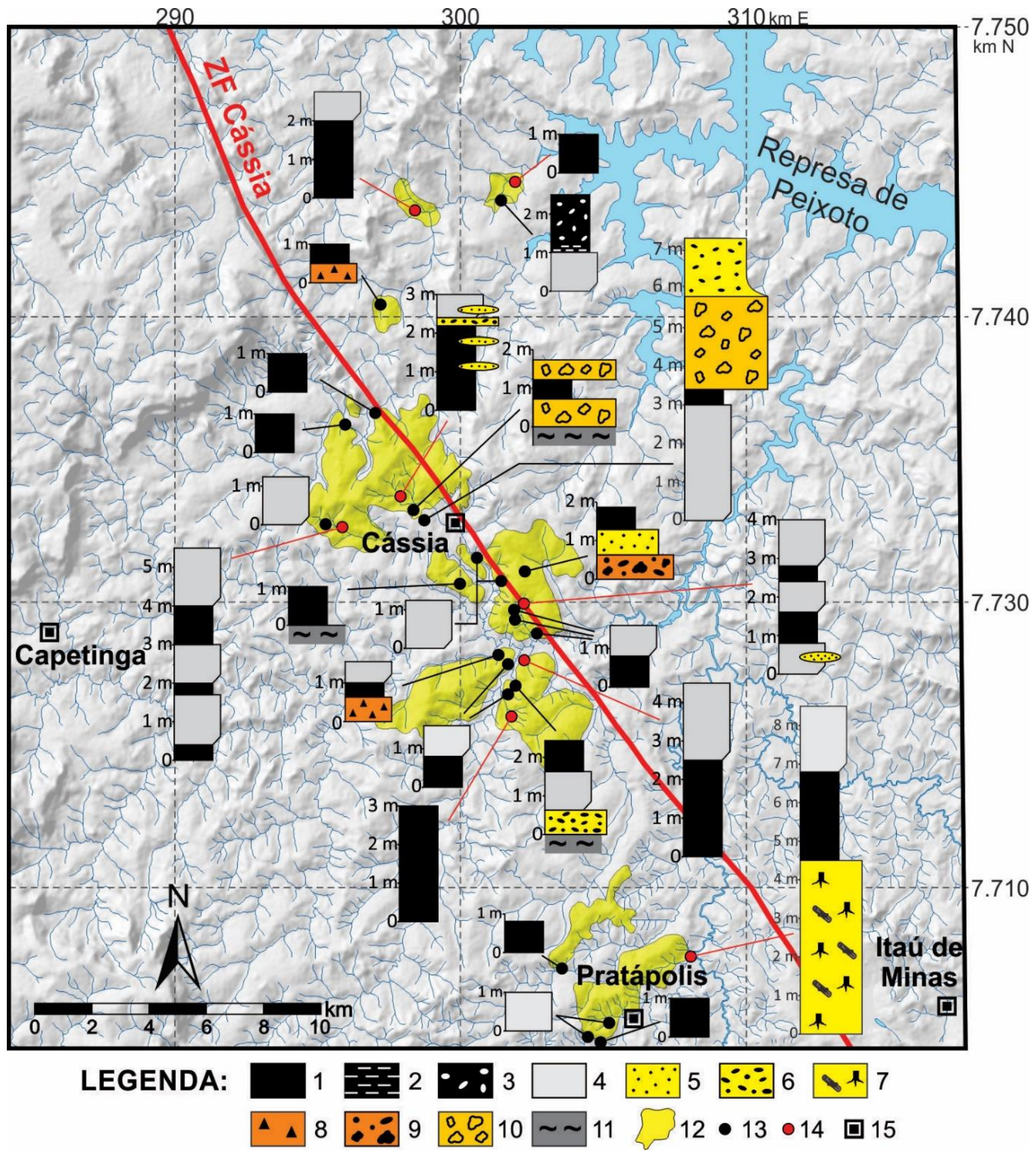

Figura 6 - Colunas estratigráficas representativas dos depósitos sedimentares quaternários do Domínio Lajeado. Ao fundo, é mostrado o relevo sombreado (iluminação segundo o azimute N45) obtido a partir de dados SRTM e o traço simplificado da Zona de Falha de Cássia. Legenda: 1 - Argilito preto; 2 - Argilito com laminação; 3 - Argilito portando clastos; 4 - Siltito arenoso; 5 - Arenito; 6 - Arenito conglomerático; 7 - Arenito contendo fragmentos de caules e troncos parcialmente carbonificados; 8 - Diamictito; 9 - Conglomerado; 10 - Brecha sedimentar; 11 - Xisto (embasamento cristalino); 12 - Limite dos depósitos sedimentares; 13 - Afloramento descrito; 14 - Afloramento amostrado para palinologia; 15 - Sede de município.

Também foi observada em alguns afloramentos (SP-46 e RM-195) uma brecha sedimentar castanho avermelhada a mosqueada, matriz arenosa a argilo-arenosa, mal selecionada, contendo fragmentos angulosos de até $20 \mathrm{~cm}$, compostos por quartzo, quartzito, muscovita xisto e arenito (Figura 5F). O litotipo grada para um arenito conglomerático no topo, perfazendo camadas de 0,5 a 4,0 $\mathrm{m}$ de espessura.

Por fim, observou-se um diamictito (pontos SP-24 e 30) castanho a ocre, matriz argilosa, contendo seixos e calhaus angulosos de quartzito, formando camadas de 30 a $70 \mathrm{~cm}$ de espessura. Tanto a brecha sedimentar quanto o diamictito apontam para chegada de fluxos de detritos, oriundos de área-fonte próxima. 


\section{ANÁLISE PALINOLÓGICA}

Durante a preparação de todas as amostras constatou-se grande quantidade de matéria orgânica, além dos palinomorfos. Este material, recuperado devido a preparação palinológica alternativa sem o uso de ácidos (Arai, 2017), é representado por abundantes fragmentos e restos de matéria orgânica lenhosa perfurada e herbácea (traqueídes e cutículas de plantas), com predomínio ora de um tipo, ora de outro.

As análises palinológicas realizadas registraram esporos e pólen de plantas viventes, sendo muitos deles identificáveis em nível de gênero e espécie. As amostras exibiram conteúdo palinológico com espectro próprio e único, refletindo em diferentes assinaturas palinológicas.
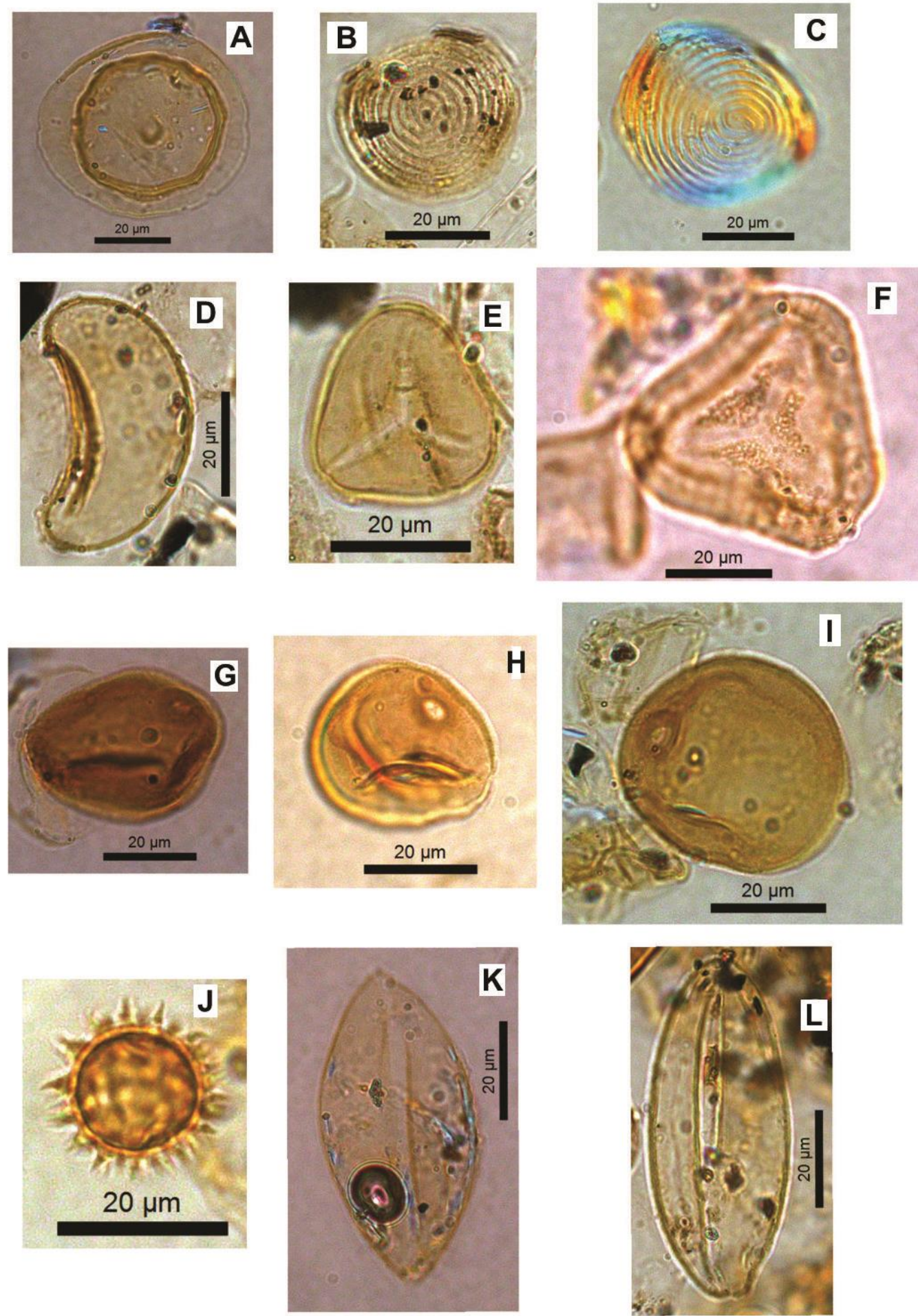

Figura 7 - A) Vista polar de microalga tipo Debarya. B, C) Microalgas tipo Chomotriletes (=Pseudoschizaea). D) Esporo monolete de Gleichenia (pteridófita). E) Esporo trilete liso de Cyatheaceae (pteridófita). F) Esporo trilete de Pityrogramma (Pteridaceae, pteridófita). G - I) Pólen monoporado de Poaceae (gramínea). J) Pólen de Asteraceae (Compositae). K, L) Pólen do tipo Monosulcites (provavelmente de Arecaceae). 
De maneira geral as amostras exibiram registro palinológico predominantemente dado por fitólitos e microalgas de água doce. Fitólitos são restos silicosos de origem vegetal produzidos principalmente por plantas da família Poaceae (gramíneas), típica de vegetação aberta (campo), e da Cyperaceae, típica de solos úmidos ou até mesmo pantanosos. Curiosamente nem todas as amostras contendo fitólitos apresentaram grãos de pólen de Cyperaceae, como pode ser observado nas amostras ZFC-03; 07A, D, E; 09A e 13 B, sugerindo maior contribuição da família Poaceae.

Elementos algáceos ocorreram em praticamente todas as amostras estudadas (à exceção das amostras ZFC-13A e B). Merecem destaque as microalgas de água doce, representadas pelos gêneros Chomotriletes/ Pseudoschizaea (Figura 7B, C), Debarya (Figura 7A), Ovoidites (Spirogyra) e Botryococcus. Deste modo, uma primeira interpretação geral é a existência de um corpo d'água permanente, onde ocorreu a deposição do argilito preto.

Adicionalmente, há o registro de vegetação de campo de clima úmido na região, representado pela ocorrência de esporos de pteridófitas (esporos monoletes - Figura 7D e triletes - Figura $7 \mathrm{E}, \mathrm{F}) \mathrm{em}$ todas as amostras analisadas. Pteridófitas requerem água para se reproduzir, portanto, sua ocorrência sistemática é indicativo de clima úmido, ao menos em uma das estações do ano, reforçando o caráter úmido do paleoambiente da região.

Por outro lado, grãos de pólen de Poaceae
(Figura 7G, H, I) e Asteraceae (Figura 7J) indicam campos bem drenados. Tais palinomorfos tem um registro importante, em especial nas amostras ZFC-02, 07B, 09B e 10B. Esta aparente contradição na interpretação paleoambiental pode ser explicada pelo fato de que os grãos de pólen destas espécies podem ter sido transportados pelo vento de locais relativamente distantes do sítio deposicional. Isto explicaria a sua coexistência com Cyperaceae e até mesmo com microalgas de água doce.

Também chama a atenção a ocorrência de grãos de pólen de plantas de grande porte como as famílias Arecaceae (Figura 7 K, L) e família Araucariaceae (gimnosperma) no registro palinológico de alguma amostras (ZFC-07C, D, $10 \mathrm{~B}$ e 13B). Embora não ocorra em grande quantidade, sua presença indica a existência de vegetação arbórea na região adjacente. Assim como ocorre para as famílias Poaceae e Asteraceae, seus grãos de pólen também podem ser transportados pelo vento. Logo, sua ocorrência reforça a hipótese de uma vegetação desenvolvida no entorno do paleolago.

A ausência de espécies palinológicas comprovadamente pré-quaternárias, sugere que a sedimentação tenha ocorrido no Quaternário. Entretanto, a abundância de elementos de campo aberto, como as famílias Poaceae e Asteraceae, aliada à relativa escassez de elementos arbóreos e à presença conspícua da microalga Debarya, um indicador de clima frio, sugere que a deposição não seja posterior a $8.000 \mathrm{AP}$.

\section{INDÍCIOS DE DEFORMAÇÃO}

Durante os trabalhos de mapeamento foi observado um afloramento (SP-47) com o registro de fortes evidências de deformação nos sedimentos argilosos. Trata-se de um argilito castanho amarelado, portador de grânulos de quartzo sobreposto a um siltito arenoso cinza a vermelho. Ambos os litotipos se mostraram fortemente oxidados e enrijecidos, reconhecidos em afloramentos alçados topográficamente, ou seja, posicionados nos interflúvios do sistema de drenagem. As feições deformacionais registradas nos depósitos quaternários são dadas por fraturas, zonas brechadas e pequenas falhas, como mostra a figura 8. A continuidade e o paralelismo verificados entre as diferentes famílias de fraturas evidenciam tratarem-se de estruturas de origem tectônica. Neste conjunto merecem destaque as falhas normais N50W/72SW e N34W/65NE, bem como uma falha transcorrente $\mathrm{E}-\mathrm{W} / 60 \mathrm{~N}$ destral, e zonas brechadas de atitude N60E/90, mostradas no estereograma da figura 9.

Infelizmente, a pequena quantidade de dados estruturais disponíveis e sua baixa distribuição no espaço impossibilitam a adequada reconstrução do campo de paleotensões. Outro fator que dificulta sobremaneira a aquisição de medidas estruturais é a contínua explotação dos depósitos sedimentares, muitas vezes seguida pelo preenchimento das antigas cavas de exploração com rejeito ou estéril. 


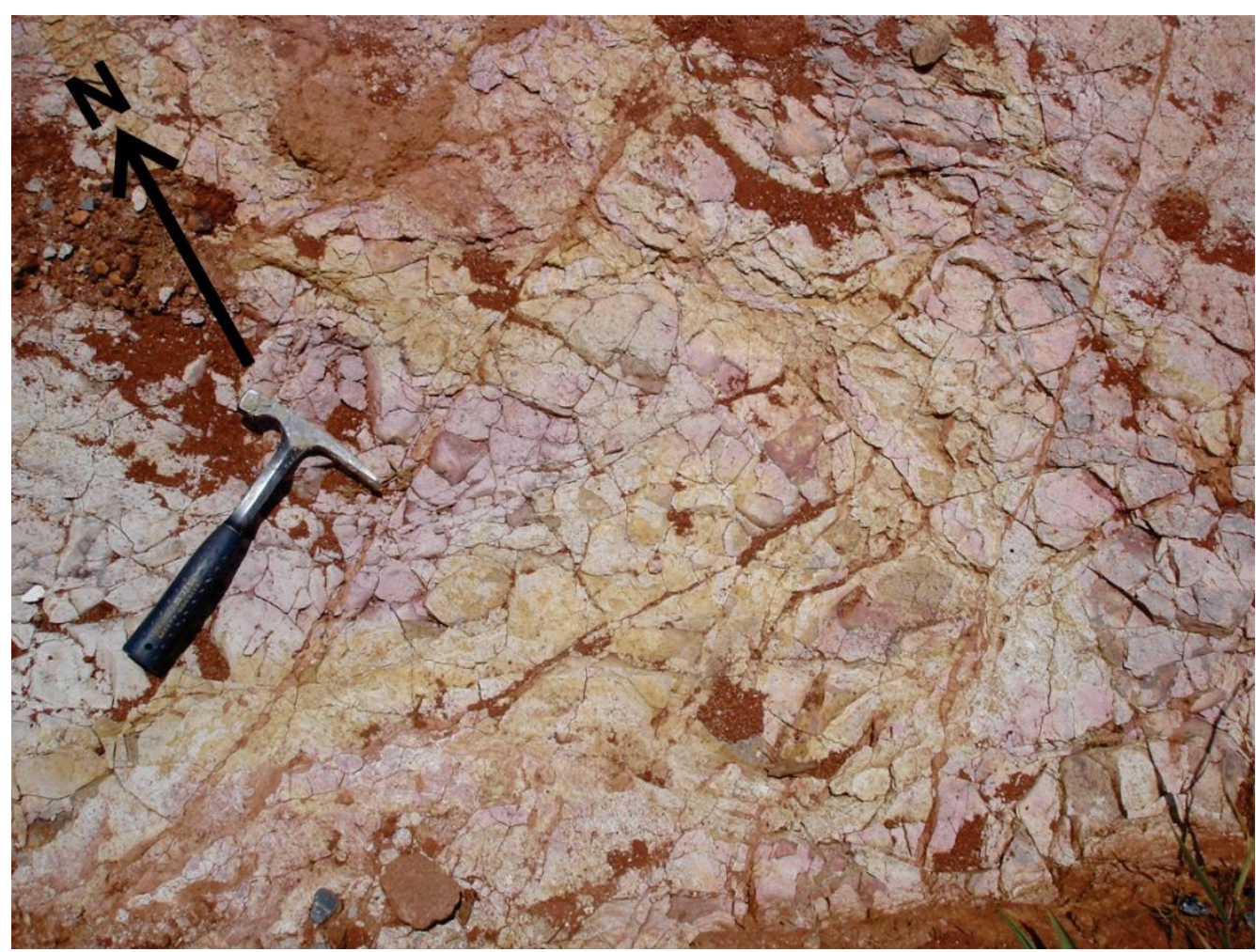

Figura 8 - Argilito quaternário oxidado e enrijecido mostrando marcante fraturamento e zonas de brechação (paralelas ao cabo do martelo). Notar a continuidade e o paralelismo entre as diferentes famílias de fraturas, indicando atividade tectônica para sua formação. Ponto SP-47.

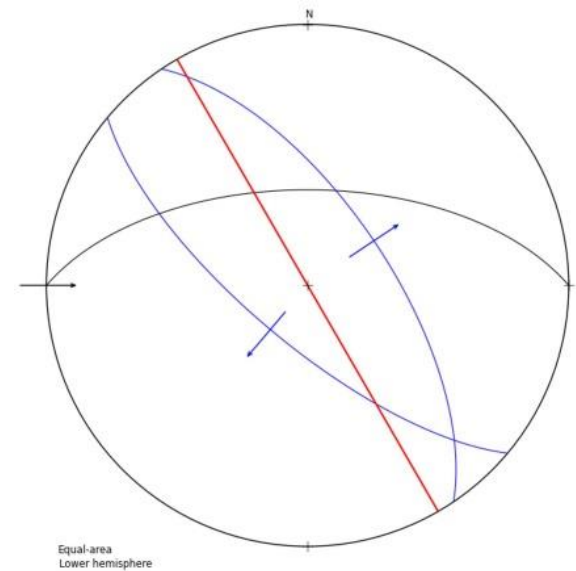

Figura 9 - Estereograma exibindo falhas normais (em azul), transcorrente dextral (em preto) e orientação das zonas brechadas (em vermelho) registradas nos sedimentos quaternários. Diagrama de Schmidt-Lambert, hemisfério inferior.

\section{GÊNESE E EVOLUÇÃO DOS DEPÓSITOS SEDIMENTARES}

A paisagem pré-atual da região estudada teria sido algo similar ao observado nos dias de hoje. Deste modo, ter-se-ia uma região deprimida esculpida nas rochas metamórficas do Grupo Araxá cortadas e deformadas pela Zona de Falha de Cássia, e limitada a oeste pelas proeminentes escarpas erosivas dos Planaltos da Bacia do Paraná (Figura 10A).

Um conjunto de indícios, discutidos mais adiante, sugerem que a Zona de Falha de Cássia teria sido reativada no Quaternário como uma falha normal, com bloco abatido a sudoeste (Figura 10B). Como consequência, teria havido o barramento da drenagem pré-atual, que passou a não mais escoar para leste, em direção ao Rio Grande, ficando confinado na região entre as escarpas da Bacia do Paraná e os traços reativados da zona de falha. Deste modo, desenvolveu-se uma ampla área alagada, dominada por águas calmas, que possibilitaram a deposição dos siltitos e argilitos, caracterizados como depósitos lacustres (Figura 10C).

$\mathrm{O}$ registro palinológico dos argilitos pretos corroboram a hipótese de um corpo d'água permanente, devido a ocorrência ampla e 
abundante de microalgas de água doce. A ocorrência generalizada de esporos de samambaias reforça a tese de um paleoambiente de clima úmido. Além disso, a palinologia indica ainda a presença de uma vegetação de campo aberto nas proximidades do lago, formada por Poaceae (gramíneas) e Asteraceae (Compositae), e vegetais de grande porte, como gimnospermas.

As brechas sedimentares e conglomerados registrados em alguns afloramentos foram interpretados como produto de processo de movimento de massa tipo fluxo de detritos, típico de leques aluviais, oriundos do bloco soerguido ou mesmo do recuo da escarpa da Bacia do Paraná a oeste. $\mathrm{O}$ diamictito, o arenito e o arenito conglomerático foram considerados como pertencentes aos fácies proximais dos leques aluviais ou decorrentes de retrabalha-mento destes sedimentos por um sistema fluvial. Deste modo, ter-se-ia o registro sedimentar dominado por pelitos lacustres entremeados pela entrada esporádica de leques aluviais (Figura 10D).
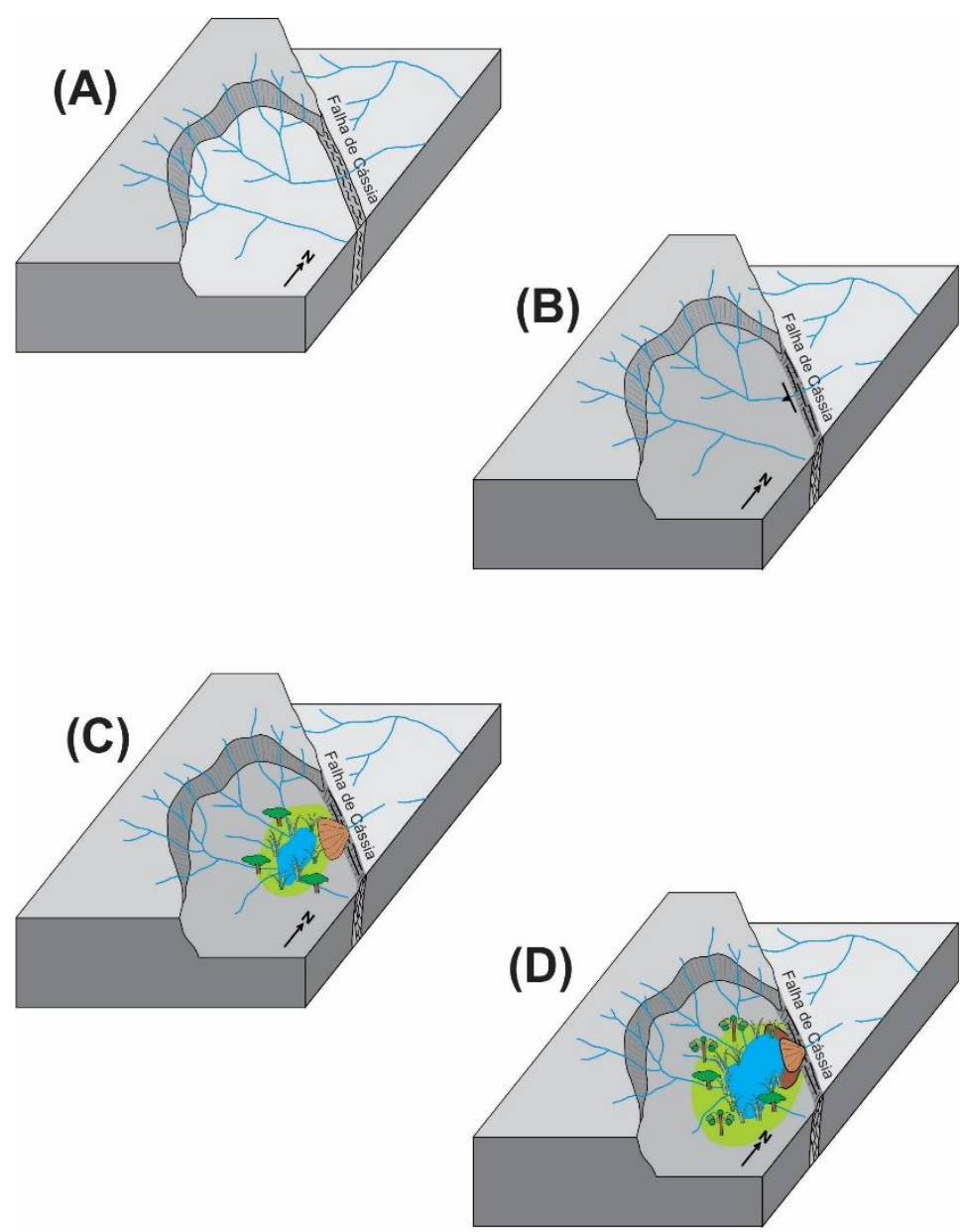

Figura 10 - Modelo evolutivo dos depósitos sedimentares da região de Cássia - Pratápolis. A) Configuração pré-atual da região. B) Zona de Falha de Cássia reativada como falha normal com bloco baixo a sudoeste, provocando o barramento da drenagem. C) Formação inicial de um lago com desenvolvimento de vegetação no entorno dada por gramíneas, samambaias e vegetais de grande porte (e.g. Araucariaceae). Desenvolvimento de leque aluvial nas proximidades da descontinuidade. D) Ampliação da área alagada e da vegetação do entorno. Formação de novos leques aluviais preservados no registro sedimentar.

\section{EVIDÊNCIAS DE REATIVAÇÃO DA ZONA DE FALHA DE CÁSSIA}

A hipótese da reativação da Zona de Falha de Cássia durante o Quaternário é sustentada pelo padrão de distribuição geográfica dos depósitos sedimentares. O mapa geológico da figura 3 mostra claramente que a cobertura sedimentar se concentra predominantemente a sudoeste da Zona de Falha de Cássia. Adicionalmente, os limites dos depósitos sedimentares são localmente retilíneos, orientados preferencial- mente segundo a direção NW-SE, paralela à zona de falha, denotando forte controle estrutural da sedimentação. Assim, tem-se o reconhecimento de um critério geométrico de reativação da Zona de Falha de Cássia.

Reforça essa hipótese o reconhecimento de extensos segmentos retilíneos de drenagem encaixados, caracterizando fortes e persistentes lineamentos de drenagem orientados preferen- 
cialmente segundo a direção NW-SE, paralelo ao traço da zona de falha como indica o mapa de drenagem da figura 11. Outros importantes tipos de anomalias de drenagem foram observados, como canais com curvatura anômala, podendo configurar inflexões abruptas com ângulo de até $90^{\circ}$, os cotovelos de drenagem. Segundo Lima (2002), tais feições geralmente estão associadas ao controle estrutural e tectônico da área, podendo ser relacionadas com falhas normais.
As drenagens em cotovelo e com curvatura anômala ocorrem distribuídas por toda a área de estudos, mas estão claramente concentradas nas proximidades de Zona de Falha de Cássia e no bloco baixo a sudoeste. Além disso, nas proximidades de Itaú de Minas há um conjunto de drenagens configurando padrão anelar (Figura 11). Segundo Lima (2002), o referido padrão de drenagem pode estar associado com uma bacia, ou seja, uma área abatida, concordando com o modelo evolutivo proposto para a região.

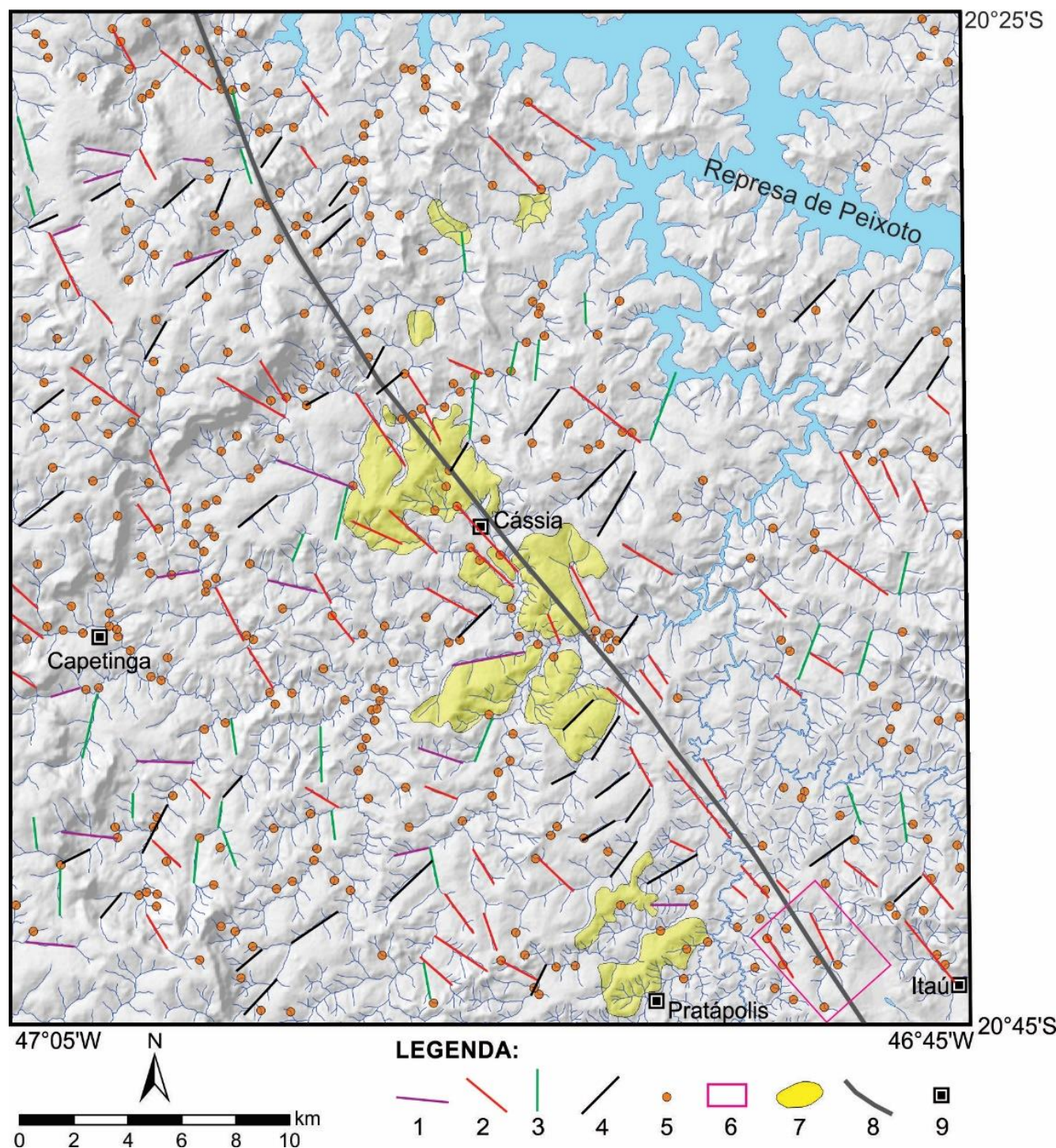

Figura 11 - Mapa de drenagem da região de Cássia-Pratápolis, destacando os lineamentos e anomalias de drenagem. Legenda: 1- lineamento E-W; 2- lineamento NW-SE; 3- lineamento N-S; 4- lineamento NE-SW; 5- drenagem em cotovelo; 6- drenagem com padrão anelar; 7- depósitos sedimentares mapeados; 8- traço principal simplificado da Zona de Falha de Cássia; 9- Sede de município.

Por sua vez, considerando o registro sedimentar dos depósitos estudados, tem-se rochas de granulação grossa como brecha sedimentar, conglomerado, arenito conglomerático, arenito e diamictito, interpretadas como oriundas de leques aluviais. Tais litologias ocorrem predominantemente nas proximidades dos traços da Zona de Falha de Cássia, como mostra a figura 5, sugerindo que os leques aluviais estejam relacionados com o desnível topográfico decorrente da movimentação/ reativação da zona de falha. Deste modo, tem-se a constituição de um importante critério estratigráfico de reativação da descontinuidade 
(sensu Holdsworth et al., 1997).

$\mathrm{O}$ registro de falhas, zonas brechadas e fraturas nos sedimentos, em arranjo seguramente tectônico pela continuidade dos traços e coerência com o quadro evolutivo regional, aponta para o reconhecimento de uma fase de ativação geradora destas estruturas descontínuas, certamente influenciadas pela Zona de Falha de Cássia. Assim, tem-se o reconhecimento em campo de um terceiro critério de reativação de falha (sensu Holdsworth et al., 1997), o estrutural.

\section{CONSIDERAÇÕES FINAIS}

Pelos estudos empreendidos constatou-se que os depósitos sedimentares de Cássia estão posicionados predominantemente nos interflúvios, situados até $140 \mathrm{~m}$ acima do nível atual das drenagens locais. O registro sedimentar é dominado por rochas de composição pelítica, com destaque para o argilito preto e o siltito arenoso variegado, interpretados como sendo de origem lacustre. Subordinadamente ocorre brecha sedimentar e conglomerado, oriundos de processo de fluxo de detritos, decorrentes da entrada episódica de leques aluviais. Os arenitos e diamictitos representariam fácies proximais dos leques aluviais, ou estariam relacionados ao retrabalhamento dos sedimentos por um sistema fluvial.

As análises palinológicas realizadas indicam que o argilito preto foi depositado em um corpo d'água permanente, provavelmente em clima frio, durante o Quaternário. A interpretação de um paleoambiente úmido é reforçada pela ocorrência sistemática de esporos (triletes e monoletes) de samambaias. Também há o registro de vegetação de campo aberto nas proximidades do lago, juntamente com alguns poucos elementos arbóreos.

A formação do paleolago estaria relacionada ao barramento do sistema de drenagem pré-atual, decorrente da reativação da Zona de Falha de Cássia como uma falha normal, com bloco baixo a sudoeste, durante o Quaternário. Sustentam essa hipótese a constatação dos seguintes critérios de reativação tectônica:

Geométrico - através do forte controle da distribuição das coberturas sedimentares pelos traços da zona de falha;

Estratigráfico - constatação de litologias de granulação mais grossa, interpretadas como provenientes de leques aluviais, aflorando preferencialmente nas proximidades dos traços de falha;

Geomorfológico - ocorrência de expressivos lineamentos de drenagem alinhados à Zona de Falha de Cássia, bem como concentração de anomalias de drenagem (curvaturas anômalas e cotovelos) ao redor da descontinuidade e no bloco rebaixado.

Portanto, pode-se concluir com segurança, que a reativação da Zona de Falha de Cássia proporcionou a geração de espaço de acomodação para a formação dos depósitos sedimentares. Adicionalmente, o reconhecimento de deformação de origem tectônica (fraturas, zonas brechadas e falhas) imposta ao pacote sedimentar quaternário reforça a hipótese de atividade neotectônica na região.

\section{AGRADECIMENTOS}

O primeiro autor (JES) agradece ao CNPq pela concessão da bolsa de doutorado (Processo $\mathrm{n}^{\circ}$ 165.801/2014-0), que possibilitou a realização dos trabalhos de campo e análises laboratoriais necessárias à elaboração deste artigo.

\section{REFERÊNCIAS}

ARAI, M. Método de preparação palinológia alternativa para sedimentos quaternários inconsolidados ou pouco litificados. In: CONGRESSO DA ABEQUA, 16, 2017, Bertioga. 2017.

AZZI, A.A. Geologia de uma área na porção centro-leste da folha Cássia (1:50.000) MG. Rio Claro, 2009. 83p. Trabalho de Formatura (Geologia) - Instituto de Geociências e Ciências Exatas, Universidade Estadual Paulista.

BATEZELLI, A. \& LADEIRA, F.S.B. Stratigraphic framework and evolution of the Cretaceous continental sequences of the Bauru, Sanfranciscana, and Parecis basins, Brazil. Journal of South American Earth Sciences, v. 65, p. 1-24, 2016.

BRASIL. Ministério das Minas e Energia. CPRM. Carta Geológica do Brasil ao milionésimo: folha SF.23 Rio de Janeiro. Brasília: CPRM, 2003. 1 CD-ROM.
CORREIA, C.T. \& GIRARDI, V.A.V. Estudo geoquímico e petrológico dos anfibolitos da região de Cássia, MG. Revista Brasileira de Geociências, v. 19, n. 1, p. 37-50, 1989.

DAEMON, R.F.; QUADROS, L.P. Bioestratigrafia do Neopaleozóico da Bacia do Paraná. In: CONGRESSO BRASILEIRO DE GEOLOGIA, 24, 1970, Brasília. Anais... Brasília: Sociedade Brasileiro de Geologia, 1970, p. 359-412.

FARIAS, F.A.; FREIRE, G.R.; LINHARES, O.A.G.; FONSECA, R.B. Mapeamento geológico e geotécnico do município de Cássia, sudoeste de Minas Gerais. Belo Horizonte, 2011. 174 p. Trabalho de Formatura (Geologia) Instituto de Geociências, Universidade Federal de Minas Gerais. FERNANDES, L.A. Estratigrafia e evolução geológica da parte oriental da Bacia Bauru (Ks, Brasil). São Paulo, 1998. 
216 p. Tese (Doutorado em Geologia Sedimentar) - Instituto de Geociências, Universidade de São Paulo.

FERNANDES, L.A.; COIMBRA, A.M. Revisão estratigráfica da parte oriental da Bacia Bauru (Neocretáceo). Revista Brasileira de Geociências, v. 30, n. 4, p. 717-728, 2000.

GATTO, L.C.S.; RAMOS, V.L.S; NUNES, B.T.A.; MAMEDE, L.; GÓES, M.H.B; DE MAURO, C.A.; ALVARENGA, S.M.; FRANCO, E.M.S.; QUIRICO, A.F.; NEVES, L.B. Geomorfologia. In: BRASIL. Ministério das Minas e Energia. Projeto RADAMBRASIL Folhas SF.23/24 Rio de Janeiro/Vitória. Rio de Janeiro: Projeto RADAMBRASIL, Levantamento de Recursos Naturais, v. 32, p. 305-384, 1983.

GONTIJO-PASCUTTI, A; BEZERRA, F.H.R.; TERRA, E.L.; ALMEIDA, J.C.H. Brittle reactivation of mylonitic fabric and the origin of the Cenozoic Rio Santana Graben, southeastern Brazil. Journal of South American Earth Sciences, v. 29, n. 2, p. 522-536, 2010.

GRAVINA, E.G.; KAFINO, C.V.; BROD, J.A.; BOAVENTURA, G.R.; SANTOS, R.V., GUIMARÃES, E.M.; JOST, H. Proveniência de arenitos das formações Uberaba e Marília (Grupo Bauru) e do Garimpo do Bandeira: implicações para a controvérsia sobre a fonte do diamante do Triângulo Mineiro. Revista Brasileira de Geociências, v. 32, n. 4, p. 545558, 2002.

HASUI, Y.; HARALYI, N.L.E. Aspectos lito-estruturais e geofísicos do Soerguimento do Alto Paranaíba. Geociências, v. 10, n. 1, p. 57-77, 1991.

HOLDSWORTH, R.E; BUTLER, C.A.; ROBERTS, A.M. The recognition of reactivation during continental deformation. Journal of the Geological Society, v. 154, p. 73-78, 1997.

IPT - INSTITUTO DE PESQUISAS TECNOLÓGICAS DO ESTADO DE SÃO PAULO. Mapa geológico do estado de São Paulo, Escala 1:500.000. São Paulo: IPT, 1981, 2 v, Série Monografias, n.6.

LIMA, M.I.C. Análise de drenagem e seu significado geológico-geomorfológico. $3^{\mathrm{a}}$ ed., 2006. Disponível em: www.neotectonica.ufpr.br/geomorfologia/1.pdf. Acessado em: 12jan2017.

MILANI, E.J.; MELO, J.H.G.; SOUZA, P.A.; FERNANDES, L.A.; FRANÇA, A.B. Bacia do Paraná. Boletim de Geociências da Petrobras, v. 15, n. 2, p. 265-287, 2007.

MORALES, N.; ZANARDO, A.; SIMÕES, L.S.A.; LEITE Jr, W.B.; SANTOS, T.E.S.S.; GODOY, L.H.; CHOUPINA, A.J.; SANTOS, A.J.; CORDEIRO, M.T.; ANNUNCIATO, N.; BARSOTTI, V.A. Geologia e recursos minerais da folha São Sebastião do Paraíso. Rio Claro: Convênio CPRM - UNESP, 2008. 1 mapa, color. $84 \mathrm{~cm} \times 119 \mathrm{~cm}$, escala 1:100.000. Acompanha relatório técnico (inédito).

NEVES, N.A.; MORALES, N.; BORGES, M.S.; EBERT, H.D. Compartimentação morfotectônica da região de Jundiaí (SP). Revista Brasileira de Geociências, v. 33, n. 2, p. 167-176, 2003.

PERDONCINI, L.C. Evolução tectono-sedimentar mesozoicocenozoica da região de Franca. Rio Claro, 2003. 217 p. Tese (Doutorado em Geologia Regional) - Instituto de Geociências e Ciências Exatas, Universidade Estadual Paulista.
SANTOS, M. Serra da Mantiqueira e Planalto do Alto Rio Grande: a bacia terciária de Aiuruoca e evolução morfotectônica. Rio Claro, 1999. 134 p. Tese (Doutorado em Geologia Regional) - Instituto de Geociências e Ciências Exatas, Universidade Estadual Paulista.

SARTORI, J.E. Caracterização estrutural da Zona de Falha de Cássia/MG. Rio Claro, 2009. 52 p. Trabalho de Formatura (Geologia) - Instituto de Geociências e Ciências Exatas, Universidade Estadual Paulista.

SARTORI, J.E. Reativação de falhas: o caso da Zona de Falha de Cássia/MG. Rio Claro, 2018. 164 p. Tese (Doutorado em Geociências e Meio Ambiente) - Instituto de Geociências e Ciências Exatas, Universidade Estadual Paulista.

SIMÕES, L.S.A. Evolução tectonometamórfica da nappe de Passos, Sudoeste de Minas Gerais. São Paulo, 1995. 149 p. Tese (Doutorado em Mineralogia e Petrologia) - Instituto de Geociências, Universidade de São Paulo.

SOARES, P.C; LANDIM, P.M.B. Aspectos regionais da estratigrafia da Bacia do Paraná no seu flanco nordeste. In: CONGRESSO BRASILEIRO DE GEOLOGIA, 27, 1973, Aracaju. Anais... Recife: Sociedade Brasileiro de Geologia, 1973, v. 1, p. 243-256.

TROUW, R.A.J.; PASSCHIER, C.; WIERSMA, D.J. Atlas of mylonites and related microstructures. Heidelberg: Springer, 322 p., 2010.

TURNER, S.; REGELOUS, M.; KELLEY, S.; HAWKESWORTH, C.; MANTOVANI, M.S.M. Magmatism and continental break-up in the South Atlantic: high precision 40Ar-39Ar geochronology. Earth and Planetary Science Letters, v. 121, p. 333-348, 1994.

UESUGUI, N. Palinologia: Técnicas de tratamento de amostras. Boletim Técnico Petrobras, v. 22, n. 4, p. 229-240, 1979.

VALERIANO, C.M.; SIMÕES, L.S.A. Geochemistry of Proterozoic mafic rocks form the Passos Nappe (Minas Gerais, Brazil): tectonic implications to the evolution of the southern Brasilia Belt. Revista Brasileira de Geociências, v. 27, n. 1, p. $99-110,1997$.

VALERIANO, C.M.; MACHADO, N.; SIMONETTI, A.; VALLADARES, C.S.; SEER, H.J., SIMÕES, L.S.A. UPb geochronology of the Southern Brasília belt (SE-Brazil): sedimentary provenance, Neoproterozoic orogeny and assembly of West Gondwana. Precambrian Research, v. 130, p. 27-55, 2004.

ZANARDO, A. Análise petrográfica, estratigráfica e microestrutural da região de Guaxupé-Passos-Delfinópolis (MG). Rio Claro, 1992. 288 p. Tese (Doutorado em Geologia Regional) - Instituto de Geociências e Ciências Exatas, Universidade Estadual Paulista.

Submetido em 7 de abril de 2018 Aceito em 3 de maio de 2019 